\section{Ultrasound scans accused of disrupting brain development}

Jim Giles, San Diego

The effect of ultrasound scans on brain development is to be investigated in a study on monkeys starting next month in the United States. The work has been prompted by unpublished research showing that ultrasound can disrupt the normal movement of cells through the brains of unborn mice.

The \$3-million study, which is funded by the US National Institute of Neurological Disorders and Stroke in Bethesda, Maryland, will examine the effect of scans on the unborn offspring of around 50 rhesus macaque monkeys. Pasko Rakic and his colleagues at Yale University in Connecticut, will expose the monkeys to ultrasound at different times during pregnancy. Brain cells of interest will be tagged with a marker molecule before the scans, and the final position of the neurons will be assessed when the animals are killed after birth.

Rakic announced the study on 24 October at the annual meeting of the Washington-based Society for Neuroscience, held in San Diego. He will not reveal details of his preliminary mice study until the latest work has been published, but he says that the scans seem to interfere with the migration of neurons from the centre of the developing brain to the cortex - the outer layer of the brain that handles everything from movement to speech.

"The cells are slowed down and more spread out," he says. "Some of them are not getting to their final destination."

The movement of neurons in the developing fetus, on which Rakic did pioneering studies during the 1970s and 1980s, is known to be disrupted by certain viruses, genetic mutations and drugs taken during pregnancy. Studies have linked such disruption to a range of human conditions, including some forms of autism and learning difficulties.

Radiologists caution that more information is needed about the ultrasound dose used on the mice before any relevance to humans can be discussed. At high doses, for example, ultrasound causes a heating effect that damages tissue. "People have been studying the effect of ultrasound on development since the 1970s," says William O'Brien, a specialist in bioacoustics at the University of Illinois at Urbana-Champaign. "We've not seen anything when levels equivalent to those allowed for humans are used."

\section{Geneticists struggle towards consensus on place for 'race'}

Meredith Wadman, Washington

The thorny question of race is set to take centre stage at the annual meeting of the American Society of Human Genetics in Toronto, Canada, this week. Leading geneticists will present perspectives on how their discipline should deal with the fraught topic.

The geneticists' views will be published in a supplement to next month's Nature Genetics, and were to be the subject of a press conference that was due to take place in Toronto on 27 October. Their views took shape at what many participants characterize as a landmark meeting in 2003 at Howard University, a historically black university in Washington DC.

The scientists" overall message is that "the traditional categories of race and ethnicity are to some extent inhibiting researchers from identifying the real environmental and genetic causes of disease," says Myles Axton, editor of Nature Genetics. "The genetic differences that are of importance in disease are not necessarily distributed according to race and ethnicity." But the authors of the supplement, whose production was sponsored by the US Department of Energy, are sharply divided on how quickly they can afford to discard 'race' as a valuable category in their work.

Francis Collins, director of the US National Human Genome Research Institute, who contributed a commentary article, says that the connections between race, genetics and disease are ripe for serious scientific study.

Unlike some of his fellow authors, Collins does not think that the concept of race should be ditched. "Throwing it away might cause us to lose some of our best clues of the causes of disease, be they genetic or environmental," he says. However, he adds, race is "a lousy proxy" for specific risk factors and researchers should dispense with it as soon as they identify pertinent factors. "It's a lot more powerful to test for sickle-cell carrier status than to look at the colour of somebody's skin," he says.

Human beings differ from each other at only about $0.1 \%$ of the genome's 3 billion bases, but it is not known whether or how those differences create disparities in disease prevalence, severity and drug response between different races. Some argue that studying this question will provide vital information for biomedical progress. Others say that this approach relies on unvalidated assumptions that race has a biological base, and plays into the hands of racists.

"Genetic variation research does not support the existence of human races. That is our overriding consensus," says contributor Charles Rotimi, acting director of Howard's human genome centre."The only way we can get to the meaning of human genetic variation is by removing racial classification in biomedical research."

"We need to make changes," agrees Charmaine Royal, a geneticist at Howard and the prime mover behind the 2003 meeting. Study designs, she suggests, should reflect subjects' geographical location and ancestry, for example, rather than their race.

But Neil Risch, a geneticist at Stanford University, California, strongly disagrees. "It's extremely important to examine disease rates in different racial groups," he says. "There is no way to address inequities in health otherwise."

Joanna Mountain, a Stanford anthropological geneticist, says that nearly all researchers agree that, ultimately, race and ethnicity need to be discarded as categories in biomedical research. "But in the short term, it may be far more efficient to use them than to ignore them. Race and ethnicity are explanatory, even if it's unclear what they are surrogates for."

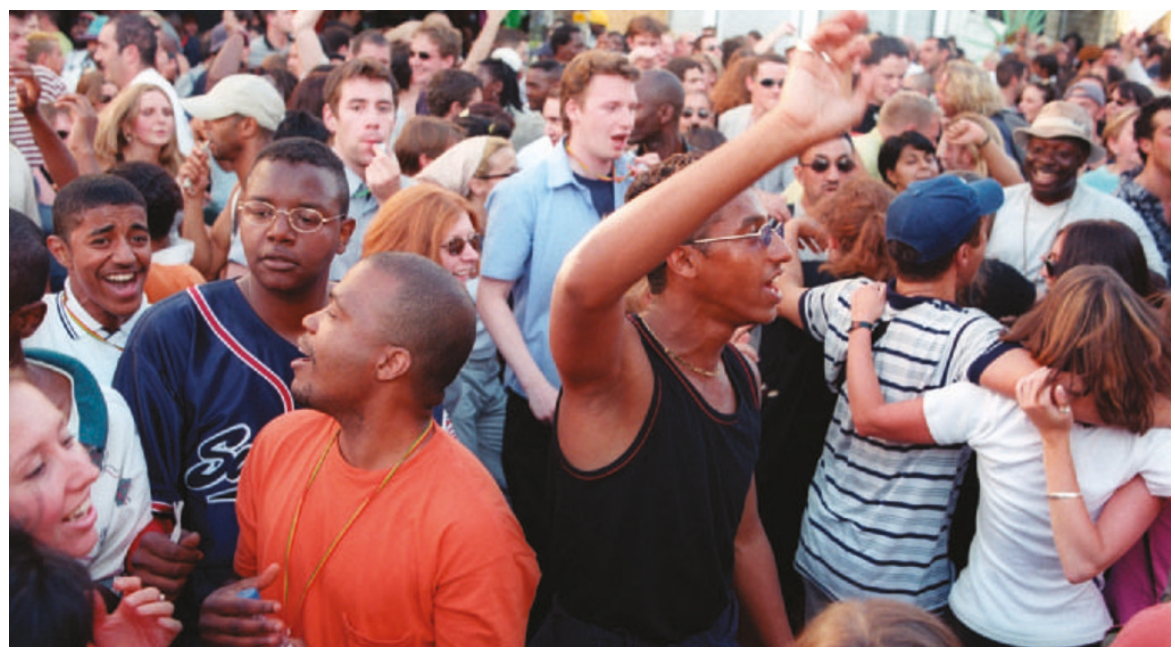

Stir it up: does race have a genetic basis that could aid biomedical research? 